\title{
VOICING THE DROWNED GIRL: POEMS BY HILDE DOMIN, ULLA HAHN, SARAH KIRSCH, AND BARBARA KÖHLER IN THE GERMAN TRADITION OF REPRESENTING OPHELIA
}

Gaps in Shakespeare's writing of Ophelia give scope for imaginative extrapolation by later writers and artists. ${ }^{\text {I }}$ They allow speculation on the mental disorder and the loveliness of the female figure, but the reworking and reception of Ophelia reflect above all 'a prevailing tendency to yoke women unreasonably with death'. ${ }^{2}$ At the end of Act IV of Hamlet the Queen reports Ophelia's drowning to Laertes; not only is it unseen on stage (unlike the male deaths), but the play never reveals who witnessed it; and whether it was suicide or accident is left ambiguous. This unseen scene develops in the mind's eye, as Gertrud Landsberg asserted in 1918:

Unauslöslich bleibt vor unserm geistigen Auge das wundersame Bild: Ophelia, blumenumrankt, 'Stellen alter Weisen' singend, mit weit ausgebreiteten Gewändern auf den Wellen schwebend, 'wie ein Geschöpf, geboren und begabt für dieses Element', bis ihre Erdenschwere sie endlich doch in die Tiefe zieht. ${ }^{3}$

The Queen's description of the drowning establishes motifs which poets echo in appropriating Ophelia for later eras. The inextinguishable image occurs at the point where her body becomes a corpse. This essay examines how four contemporary poems in German operate in the representational fissures of Shakespeare's play and disrupt prevailing lyric representations of the drowned girl. These poems, by Hilde Domin, Ulla Hahn, Sarah Kirsch, and Barbara Köhler, perpetuate and revise the Ophelia myth in the I980s and I990s; their intertexts include not only Hamlet, but also the German reception of Ophelia spanning the century before them. The poems refute the idea, articulated in 2003 by Audrey Kerr, that 'the Ophelia image, traditionally anyway, pushes no boundaries, challenges no stereotypes, rewrites no conventions' ${ }^{4}$ They will therefore be treated as fundamentally in dialogue with the tradition of Ophelia representations.

Although Hamlet translations were published in the eighteenth century (by Wieland in I766 and by A. W. Schlegel in I 798), in German-language culture the meaning of Ophelia was contested, above all, in the twentieth century. It has been contested by a succession of major poets, in the Weimar Republic, in the GDR, in West Germany, in Austria, and in united Germany. In different

\footnotetext{
${ }^{\text {I }}$ Elaine Showalter has highlighted the appropriation of Ophelia by non-German writers and artists. See 'Representing Ophelia: Women, Madness and the Responsibilities of Feminist Criticism', in 'Hamlet': William Shakespeare, ed. by Susanne L. Wofford (Boston and New York: Bedford and St Martin's Press, I 994), pp. 220-40 (p. 221).

${ }^{2}$ Beth Ann Bassein, Women and Death: Linkages in Western Thought and Literature (Westport, CT, and London: Greenwood, I984), p. x.

3 Gertrud Landsberg, Ophelia: Die Entstehung der Gestalt und ihre Deutung (Cöthen: Schulze, I9 18$)$, p. 85

${ }^{4}$ Audrey Kerr, review of Carol Solomon Kiefer, The Myth and Madness of Ophelia, in Sixteenth Century fournal, 34 (2003), 605-06 (p. 606).
} 
ways, they acted on the supposition of Edgar Allan Poe in 1846 , that 'the death of a beautiful woman is unquestionably the most poetical topic in the world'. ${ }^{5}$ Poems evoking the dead or dying Ophelia appear within diverse conceptions of what constitutes 'poetical', including those associated with Expressionism, 'Trümmerliteratur', the Viennese avant-garde, and i 970 s 'Alltagslyrik'. When poets in the I980s and I990s invoke Ophelia figures, they are therefore writing within an established tradition of German Ophelia poems. Günter Kunert's poem 'Teatrum mundi', from his collection Abtötungsverfahren, opens with the statement 'Täglich treibt Ophelia / an dir vorbei'. 6 This conceit fosters a sense that Ophelia's appearances proliferate in the contemporary world; in this, it corresponds to Tom Hunter's 2000 photograph 'The Way Home', whose embowered woman cites John Everett Millais's famous Ophelia oil painting of I 852 . It reappropriates Shakespeare's drowned girl for the turn of the millennium by placing her in a contemporary suburban wasteland, as though she has been adrift for centuries. The Ophelia tradition in visual art is an influential precursor of the lyric tradition evoking an Ophelia pallid and immobile in the water. In poetry, as in art, Ophelia is never buried, but always drifting past as the water-borne corpse: treiben becomes the key verb associated with Ophelia in German poetry.

The 'first-generation' Ophelia poems in German were written in the second decade of the twentieth century, under the auspices of Expressionism. The four well-known ones are Georg Heym's 'Die Tote im Wasser' and 'Ophelia' (published in I9 I I in Der ewige Tag), Gottfried Benn's 'Schöne Jugend' (published in I 912 in his Morgue sequence), and Bertolt Brecht's 'Vom ertrunkenen Mädchen' (published in I919-20 in Baal and later as a stand-alone poem in Hauspostille). Contrary to Rainer Nägele's assertion that Brecht's is 'one of the last', ${ }^{7}$ subsequent Ophelia poems far exceed in number the Expressionist ones. Ophelia as a rhetorical figure remains active: in the I940s and I950s, in poems by Johannes R. Becher, Johannes Bobrowski, Erich Fried, and Gerhard Rühm; in the I960s and I970s, in poems by Kurt Bartsch, Nicolas Born, Paul Celan, Peter Huchel, and Wolfgang Hilbig; and in the I980s and I990s, in poems by Hilde Domin, Durs Grünbein, Ulla Hahn, Sarah Kirsch, Barbara Köhler, Günter Kunert, and Richard Pietrass. Poems throughout the period from i9 Io to 2000 demonstrate the sheer persistence and prevalence of the myth. But only in the 1980 s do female poets writing in German begin to represent Ophelia. Drawing together the poems of Domin, Hahn, Kirsch, and Köhler, and comparing them with earlier contributions to the Ophelia myth, reveals how the inscription of her silence is overturned. In order to appreciate the shift which occurs, it is useful to measure the extent to which preceding Ophelias embody silence.

As the drowned girl, Ophelia is distinct from other women of the water whom

${ }^{5}$ Edgar Allan Poe, 'The Philosophy of Composition', in Complete Poems and Selected Essays, ed. by Richard Gray (London: Dent, I 993), pp. I05-I 4 (p. I09).

${ }^{6}$ Günter Kunert, 'Teatrum mundi', in So und nicht anders: Ausgewählte und neue Gedichte (Munich and Vienna: Hanser, 2002), p. 65.

${ }^{7}$ Rainer Nägele, 'Phantom of a Corpse: Ophelia from Rimbaud to Brecht', $M L N$, I 77 (2002), Iо69-82 (p. 1069). 
poets sing. Unlike Venus, who rises from the sea at her birth, Ophelia is confined to the water and ends there. (Should she be removed to lie in a morgue, she invariably loses her name, as is the case with Gottfried Benn's and Paul Zech's Wasserleichen.) Unlike the mermaids, Melusina and Undine, Ophelia has no agency, but floats passively away. It is the texture of her death in Shakespeare's play which is crucial to later poets' refractions. The drowned female corpse, observed from afar, becomes a silent muse inspiring the poem; she is always its envisioned object, the antithesis of its voice. In such works, Ophelia tends not to serve as a memento mori for readers, for there is no invitation to identify with her. Three pre-war Ophelia poems, belonging with the Heym-Benn-Brecht group chronologically, but less known than those, are Georg Trakl's 'Wind, weiße Stimme', Alfred Lichtenstein's 'Der Fall in den Fluß', and Paul Zech's 'Wasserleiche'. ${ }^{8}$ Each traces a vision from afar, from the past, distancing the silent Ophelia figure from the observing voice of the poem. Lichtenstein's folksy ballad corresponds to the strumpet aspect of the tradition, her madness modernized as drunken lasciviousness. The lyric voice here belongs to the voyeur so often found ogling the drowned women of poetry. Zech's poem recollects a female corpse 'namenlos' and unclaimed, caught in a net with other sea creatures, exposed 'vor dem Gafferschwarm'. Such poems of spectatorship, like Heym's, Benn's and Brecht's, do not address the drowned woman. This serves to emphasize that she is apart and devoiced.

Throughout the tradition, Ophelia's silence corresponds to her pallor. White is the colour of death, blankness and erasure, as well as innocence. Brecht refers to 'ihr bleicher Leib'; in Heym's 'Die Tote im Wasser' she is 'bleiweiß', 'ein weißes Schiff', clad in 'ein weißes Tanzkleid' and the light 'wie eine weiße Haut'. Zech's 'Wasserleiche' is 'mondweiß'. In the twentieth century, Ophelia seems to be inextricable from the facile ideal of whiteness associated with nineteenth-century visions of the female body. As Heym's 'der weiße Strom' in the poem 'Ophelia' transfers the whiteness from the female figure to her surroundings, Peter Huchel's 'Ophelia' poem refers to 'die weiße Dämmerung' and in 'Die Hamletmaschine' Heiner Müller leaves her mummified in whiteness, 'reglos in der weißen Verpackung'. ${ }^{9}$ Wolfgang Hilbig refers to 'ihre bleiche stirn', 'ihr weißer wahnsinn', 'ihr altes weißes haar', and 'ihre weißen fingernägel'. ${ }^{\circ}$ All this whiteness means that Ophelia is packaged as blank: the withdrawal of speech and her deathly prostration preclude the depth of a person and instead iconographize her as surface and sign. Whiter than white, she is deader than dead, an epitome of speechlessness. Like Eustacia in Thomas Hardy's The Return of the Native of i 878 , the luminously pallid, eternally rigid corpse eclipses the living, speaking female:

${ }^{8}$ Georg Trakl, 'Wind, weiße Stimme: r. Fassung', in Dichtungen und Briefe, ed. by Walther Killy and Hans Szklenar, 2 vols (Salzburg: Müller, I 969), I, 3 I 9; Alfred Lichtenstein, 'Der Fall in den Fluß', in Dichtungen, ed. by Klaus Kanzog and Hartmut Vollmer (Zurich: Arche Verlag, I 989), pp. 29-30; Paul Zech, 'Wasserleiche', in Ausgewählte Werke, ed. by Bert Kasties in collaboration with Dieter Breuer, 5 vols (Aachen: Shaker Verlag, I 998-200 I), I: Gedichte (200I), p. I 54.

9 Peter Huchel, 'Ophelia', in Gesammelte Werke, ed. by Axel Vieregg, 2 vols (Frankfurt a.M.: Suhrkamp, ı 984), r: Die Gedichte, p. I75; Heiner Müller, 'Die Hamletmaschine', in Mauser (Berlin: Rotbuch Verlag, I 978), pp. 89-97.

Io Wolfgang Hilbig, 'ophelia', in abwesenheit: gedichte (Frankfurt a.M.: Fischer, I 979), pp. 72-75. 
They stood silently looking upon Eustacia, who, as she lay there still in death, eclipsed all her living phases. Pallor did not include all the quality of her complexion, which seemed more than whiteness; it was almost light. The expression of her finely-carved mouth was pleasant, as if a sense of dignity had just compelled her to leave off speaking. Eternal rigidity had seized upon it $[\ldots]^{1 \mathrm{I}}$

Against the background of Ophelia's traditional pallor, Trakl's 'Wind, weiße Stimme' seems to refer to the ghostly whispering of Ophelia; this wind is a voice without language, a white voice with no words at all.

The poets represent an Ophelia who has left off speaking. Composers' reception of Ophelia begins, however, with a singing rather than a silent Ophelia. In contrast to poets, who follow Poe's dictum, they tend to evoke a living Ophelia; the wandering girl predominates, erotically singing her loopy songs. But even in her musical reception there is, in time, a tendency to devoice Ophelia: whereas Johannes Brahms and Richard Strauss produced Lieder setting German translations of Ophelia's songs from Shakespeare, in I 946 John Cage composes an 'Ophelia' piano solo for dance, in I 975 Oliver Knussen's 'Ophelia dances' are for nine instruments (without voice), and in 1987 Richard Rodney Bennett composes a cantata on Rimbaud's 'Ophélie' poem of $\mathrm{I} 870$. This poem, like the later lyric reception of Ophelia in German, observes the water-borne corpse.

Like the Rimbaud poem, the Expressionist-era Ophelia poems polarize the observing lyric subject and the female object of its gaze in terms of voice and visibility: the speaker is invisible; the visible body deprived of voice. What is more, the voice of the poem never addresses the drowned or drowning woman, but retains a detachment from her. This is superseded first with a rhetorical question in Johannes Bobrowski's 'Ophelia', then with a sustained address to a familiar 'du' in Ophelia poems by Erich Fried and Paul Celan. ${ }^{12}$ While observation remains the dominant mode, in Bobrowski's poem we overhear a question:

Wie sag ich's recht, Ophelia? Die Wellen

Gehn leicht, wie Atem leicht, nur kühler, fremder,

Gewirr von Sternen treibt an ihren Rändern,

Hebt sich und sinkt . . . Und deines hellen Haares

Gelöste Strähne trieb darin wie eines

Vom Grunde losgeriss'nen Krautes Rest.

In the question 'Wie sag ich's recht, Ophelia?' lies a sense of responsibility to mediating her story correctly. The speaker of Bobrowski's poem, watching water submerging her hair and face, appeals to her for assistance rather than proffering any to the drowning woman. Twice his cry 'Ophelia!' occurs in the final stanza, but there is no reply at this stage in the tradition. A bird's 'Schrei' only points up Ophelia's missing voice. Instead, as in Shakespeare, the

i Thomas Hardy, The Return of the Native (London: Penguin, I 999), p. 367.

I2 Johannes Bobrowski, 'Ophelia', in Gesammelte Werke, ed. by Eberhard Haufe, 6 vols (Berlin: Union Verlag, I987), II: Gedichte aus dem Nachlaß, pp. 85-86; Erich Fried, 'Ophelia I 945', in Gesammelte Werke, ed. by Volker Kaukoreit and Klaus Wagenbach, 4 vols (Berlin: Wagenbach I 998), I: Gedichte I, 'Von Bis nach Seit: Gedichte aus den Jahren I 945-1 958', p. 75; Paul Celan, 'Du liegst', in Werke: Tübinger Ausgabe, ed. by Jürgen Wertheimer, 9 vols (Frankfurt a.M.: Suhrkamp, I 996-2004), vir: Schneepart, ed. by Heino Schmull in collaboration with Markus Heilmann (2002), p. 7 . 
willow is present, to connote her grief and broken-heartedness. Shepherds bring Ophelia's 'Botschaft', like the reporting lyric voice, speaking on her behalf. This epitomizes the tradition of Ophelia mediated by messenger figures.

With the shift from mere visibility to familiar address, Ophelia also becomes embedded in political history. Fried's 'Ophelia I945' and Celan's 'Du liegst' render the political activist Rosa Luxemburg a silent body in the water. Her decayed corpse was pulled from the Berlin Landwehrkanal in r9i9, three months after she had been shot. The two poems demonstrate how the drowned girl is addressed as victim of a political crime. Earlier in the tradition, installing the reader as spectator of Ophelia's watery passivity was first for erotic effect. There, Lichtenstein's poem watching male sexual pursuit and Zech's poem recounting a sex murder referred to the criminal-erotic. Gerhard Rühm's 'Ophelia' poem of I 956 appropriates this aspect of the Ophelia myth, evoking her flight from sexual pursuit through the voice of a deranged voyeur. ${ }^{13}$ After the Second World War, however, there is another development, where the erotic subsides and is superseded by the political-historical crime. Thus in the first stanza of Fried's 'Ophelia I 945', a command to sing draws attention both to the perpetrators of the crime and to her silence:

Ophelia, du der Fische nasse Geliebte

Sing: 'Es schwimmt eine Leiche im Donaukanal'.

In this poem, Ophelia's history as Hamlet's love is ironized. 'Es schwimmt eine Leiche im Landwehrkanal' was a music-hall song which referred to the unloved poor drowning themselves in despair; the version with 'Donaukanal' was sung in Vienna. As Fried's note accompanying the poem indicates, it became associated with mockery of the murdered Luxemburg. In German poetry, Luxemburg's death is a vital component within the Ophelia myth. Fried writes Luxemburg-Ophelia as a drowned 'du', a watery beloved, belonging with the fish and commanded 'Verströme, Mädchen!'. Besides the song adopted by the Freikorps, the bullet, absent as a motif in Shakespeare and in pre-war Ophelia reception, refers to the political killing. It is by no means necessary to see Luxemburg as an Ophelia figure, as her many other representations in poetry indicate. Indeed, Ophelia's conventional silence completely reverses the historical Luxemburg's political activism.

Celan's poem 'Du liegst' of I 967 addresses another silenced LuxemburgOphelia figure:

$$
\begin{aligned}
& \text { Du liegst im großen Gelausche, } \\
& \text { umbuscht, umflockt. } \\
& \text { Geh du zur Spree, geh zur Havel }
\end{aligned}
$$

This opening is located at a moment before the drowning, for the imperative to go to the Berlin rivers suggests avoiding the Landwehrkanal. The injunction receives no response: by the fourth stanza, the drowning has occurred, as the lyric voice echoes the perpetrators: 'die Frau | mußte schwimmen, die Sau'. Their violence is a gap circumscribed by the slip from present to past

\footnotetext{
${ }^{13}$ Gerhard Rühm, 'Ophelia', in fenster: texte (Reinbek: Rowohlt, I968), pp. 94-96.
} 
tense. Their misogyny and anti-Semitism shakes the poem, and even the water colludes in making no sound to mark the crime:

Der Landwehrkanal wird nicht rauschen.

Nichts stockt.

This closing stanza refers back to instances of pathetic fallacy, to Shakespeare's 'weeping brook' and Bobrowski's 'die Wasser schwiegen, da sie ihren leichten | entseelten Körper an das Ufer trugen'. Celan's de-eroticized Ophelia has no effect on nature; rather her victimhood is concealed by it, 'umbuscht', 'umflockt'. Celan represents the embowered Ophelia as a silent victim; the lyric voice rather adopts the words of her persecutors. Thus, despite such moments of familiar address, distance is always maintained from the drowned girl. She is only drawn into proximity by the female poets of the i 980 s and I990s, her voice becoming there the 'ich' of the poem for the first time.

The opening stanza of Barbara Köhler's poem 'Über die Brücke' uses the traditional trope of Ophelia drifting in the water. ${ }^{14}$ But this is no observed scene; the lyric 'ich' in this poem is requesting Ophelia's identity:

$$
\begin{aligned}
& \text { laß mich deine ophelia sein clown } \\
& \text { laß mich treiben wie eine welle } \\
& \text { das wasser ist tief und geh ich drauf } \\
& \text { ist es ein seil das trägt }
\end{aligned}
$$

The simile of this opening stanza emphasizes Ophelia's traditional affinity with the water. Where earlier poets repeatedly envisaged the woman erased by the water, this poem reverses that erasure. Brecht's 'ertrunkenes Mädchen', for instance, decays and is forgotten piecemeal:

$$
\begin{aligned}
& \text { Als ihr bleicher Leib im Wasser verfaulet war } \\
& \text { Geschah es (sehr langsam), daß Gott sie allmählich vergaß } \\
& \text { Erst ihr Gesicht, dann die Hände und ganz zuletzt erst ihr Haar. }{ }^{15}
\end{aligned}
$$

For Brecht, the girl is 'die Leiche', whereas in Köhler's poem we overhear a voice declaring 'laß mich deine ophelia sein'. After so many previous lyric subjects have watched Ophelia's erasure, its completion coinciding with the closing of Brecht's poem, Köhler's lyric subject volunteers to replace the lost Ophelia. Even as late as in Wolfgang Hilbig's 'ophelia' poem, in the collection abwesenheit, she dissolves in the water:

$$
\begin{aligned}
& \text { und sie ward endlich eins mit ihrem treiben } \\
& \text { und teilte sich auf in wassern und schlamm }
\end{aligned}
$$

Not disintegration in water, not abwesenheit, but a way across, a passage or

${ }^{\text {I4 }}$ Barbara Köhler, 'Über die Brücke', in Deutsches Roulette: Gedichte I984-I989 (Frankfurt a.M.: Suhrkamp, I 991), p. 76.

${ }_{15}$ Bertolt Brecht, 'Vom ertrunkenen Mädchen', in Werke, ed. by Werner Hecht, Jan Knopf, Werner Mittenzwei, and Klaus-Dieter Müller, 30 vols (Frankfurt a.M.: Suhrkamp; Berlin, Weimar: Aufbau Verlag, I 988-2000), xI: Gedichte I: Sammlungen I $918-1938$, ed. by Jan Knopf and Gabriele Knopf ( 1988 ), p. го9. On this poem see Nägele, 'Phantom of a Corpse: Ophelia from Rimbaud to Brecht', and Hilda M. Brown, 'Reading the Drowned Girl: A Brecht Poem and its Contexts', in Empedocles' Shoe: Essays on Brecht's Poetry, ed. by Tom Kuhn and Karen Leeder (London: Methuen, 2002), pp. 78-88. 
transfer, is perceived in Köhler's Ophelia poem. This is akin to the 'links between Köhler's water imagery and reflections on subjectivity' identified by Margaret Littler and to Georgina Paul's sense of 'winning movement out of myth' elsewhere in Köhler's poetry. ${ }^{16}$ The water now corresponds to a notion of Ophelia as fluid, not because she disintegrates, but because she is rewritten; she is unfixed. In the water as a means of movement otherwise denied, it recalls a less radical version of the motif in Richard Pietrass's poem 'Ophelia': ${ }^{17}$

$$
\begin{aligned}
& \text { Es nahm der Fluß sie stumm in seinen Lauf. } \\
& \text { Es hielt sie, da sie reglos trieb, nichts auf. }
\end{aligned}
$$

Whereas for Köhler's would-be Ophelia the water is 'ein seil das trägt', this river is explicitly 'stumm', something that applies implicitly to waters throughout the myth. Prevented from leaving, Pietrass's Ophelia is compelled to the water.

$$
\begin{aligned}
& \text { Ins Wasser ging, die man nicht gehen ließ } \\
& \text { Die von der Kante man des Tisches stieß } \\
& \text { Unbenutzt und stark. } \\
& \text { Da sprach sie wach. Lieber tot im Sarg. }
\end{aligned}
$$

Pietrass's poem overtly thematizes female voice; the woman who claims a political voice must be silenced. But in Köhler's poem, where the water also offers an exit strategy, we overhear an active voice issuing imperatives. Like the poems by Brecht and Hilbig, Pietrass's poem regards Ophelia in retrospect, whereas Köhler's poem uses the present. Her addressee is 'clown' and 'liebster clown', a reference to the gravediggers Shakespeare calls 'clowns' in Act v of Hamlet, who dig Ophelia's grave. Köhler does not use the German 'Totengräber' (as in Wieland's and Schlegel's translations), but rather the lexis which makes dual reference to the only discussion of Ophelia's suicide in the play and, more overtly, to the circus. This introduces a playfulness alien to the Ophelia tradition: the circus represents light entertainment, the spectacle of 'die seiltänzerin | ophelia' (in the second stanza) and a clown inducing laughter.

The role desired is not that of Hamlet's Ophelia but a clown's Ophelia, yet this is a love poem. In the closing stanza, the omission of a comma allows 'sein' to coexist in two syntactical units, so that the fugitive phrase 'sein spiel' allows a reference to the otherwise absent Hamlet:

$$
\begin{aligned}
& \text { mach mich ein bißchen wahnsinnig du } \\
& \text { laß mich deine ophelia sein spiel } \\
& \text { meinetwegen verrückt aber spiel mir } \\
& \text { bloß nicht den hamlet }
\end{aligned}
$$

Köhler's Ophelia reclaims her madness in the flirty imperative 'mach mich ein bißchen wahnsinnig du'. Her challenge returns the erotic to the Ophelia poem, but changes the subject. The erotic is verbalized by the female figure

\footnotetext{
I6 Margaret Littler, 'Rivers, Seas and Estuaries: Margins of the Self in the Work of Barbara Köhler', in Nachdenken über Grenzen, ed. by Rüdiger Görner and Suzanne Kirkbright (Munich: iudicium, I 999), pp. I 91-207 (p. 202); Georgina Paul, 'Multiple Refractions, or Winning Movement out of Myth: Barbara Köhler's Poem Cycle "Elektra. Spiegelungen”, German Life and Letters, 57 (2004), 2 I-32.

${ }^{17}$ Richard Pietrass, 'Ophelia', in Was mir zum Glück fehlt: Gedichte (Frankfurta.M.: Frankfurter Verlagsanstalt, i 989 ), p. 8 I.
} 
who, previously in the lyric tradition, was a visualized object. By contrast, in Trakl's poem 'Wind, weiße Stimme', Ophelia is only a figment of the sleeper's imagination; she walks as a dream-figure and whispers as the wind, her madness a floral fragility. Köhler's lyric subject is no unfortunate love object, but a commanding beloved who plays with preconceptions of her 'sanftes Gehaben des Wahnsinns' ('Trakl). Her voice inverts the passivity and silence which had defined her as an erotic vision.

With 'spielen', Köhler highlights the role-play, something implicit in the entire lyric tradition appropriating a theatrical figure, and first made explicit in Bonaventura's Nachtwachen of i 804. There in the fourteenth 'Nachtwache' the narrator, who has played the role of Hamlet at the Hoftheater, recounts how the actress playing Ophelia on stage loses her mind:

Die mächtige Hand des Shakespear, dieses zweiten Schöpfers, hatte sie zu heftig ergriffen, und liess sie zum Schrecken aller Gegenwärtigen nicht wieder los. Für mich war es ein interessantes Schauspiel, dieses gewaltige Eingreifen einer Riesenhand in ein fremdes Leben, dieses Umschaffen der wirklichen Person zu einer poetischen. ${ }^{\mathrm{I}}$

The image of the writer's giant hand rendering the woman ('ein fremdes Leben') a poetic character seems apposite to consideration of why Ophelia is being reclaimed in the I 980 s. The fictional letters of the 1804 text open with Hamlet's apostrophe 'Himmlischer Abgott meiner Seele, reizerfüllte Ophelia!' (p. I I 7), designating her an unambiguous love-object. On the other hand, Ophelia's first letter opens: 'Liebe und Haß steht in meiner Rolle' (p. I I 9). The Nachtwachen present Ophelia in prose letters, where her voice contends with that of Hamlet. She articulates hate, as well as love, and a sense of role apart from her self, which is taken up hundreds of years later by Köhler: 'aber die Rolle ist nicht Ich. Bring mich nur einmal zu meinem Ich, so will ich es fragen, ob es dich liebt' (p. I 20). The voice of Köhler's poem which declares 'spiel mir bloß nicht den hamlet' is continuous with this knowing Ophelia. Just before the former lines on the Ophelia role and the 'ich', from the Nachtwachen, come the lines quoted as the first motto of the collection in which Köhler's Ophelia poem was published:

Ich möchte gern mich auf einen Augenblick mit mir selbst unterreden, um zu erfahren, ob ich selbst liebe, oder nur mein Name Ophelia - und ob die Liebe selbst etwas ist, oder nur ein Name. (p. I 20)

The doubling of the 'ich' here-as self and as Ophelia-corresponds to an interrogation of love. All the poems voicing Ophelia engage with the love relationship by excising Hamlet and contemplating how the role of the beloved is at odds with the self. Thus Köhler's poem uses the name Ophelia to contrast the pallid immobility of the traditional beloved, with a mobile self crossing the high wire.

Sarah Kirsch's five-line poem 'Ich Freiwild' casts the lyric subject as another watery beloved and doubles Ophelia to figure separately her wooing and her drowning. ${ }^{19}$ The male lover becomes the river, the beloved a self exposed and unprotected, 'Ich Freiwild':

I8 Bonaventura, Nachtwachen, ed. by Hermann Michel (Berlin: Behr, I 904), p. I I 4.
i9 Sarah Kirsch, 'Ich Freiwild', in Bodenlos: Gedichte (Stuttgart: DVA, I996), p. 46. 
Der Fluß hielt gestern an

Um meine Hand sein Spiegel

Zeigt mir die

Tote Schwester im

Seerosenkranz

While primarily alluding to betrothal, the opening line of Kirsch's poem replies to and rejects the closing 'Nichts | stockt' of Celan's Luxemburg-Ophelia poem 'Du liegst'. The 'Ich' of Kirsch's poem, asserted in the title, identifies Ophelia as a dead sister in the river. What one sees in a mirror, however, is one's own reflection. Like Tennyson's Lady of Shalott (a figure at least tangential to the Ophelia myth by virtue of her floating dead in the river), she sees her fate in the mirror. The dead woman's 'coronet weeds' (Shakespeare) are 'Seerosen', like Tennyson's and Rimbaud's water lilies. The recognition of sorority in Kirsch's poem turns against Gottfried Benn's ironic reference to a 'Schwesterchen' in his famous second Morgue poem. ${ }^{20}$ Benn's line 'Ein kleines Schwesterchen lag tot' refers to a rat, for drowned women are never construed as anyone's little sister before Kirsch. Kirsch's lyric 'ich' cuts in with a declaration of sisterhood at an earlier stage in the story than Benn's 'Mädchen, das lange im Schilf gelegen hatte', who is already on display in the morgue. The bridal wreath Kirsch's drowning woman wears becomes a funeral wreath, as she is 'die / Tote Schwester', the adjective emphasized by its position at the start of the line. At Ophelia's burial, Shakespeare has a priest say: 'here she is allow'd her virgin crants' (V. I. 255). But the wreath is also one of the 'fantastic garlands' (IV. 7. I69) which in Schlegel become 'phantastische Kränze'; in Wieland's rendering of the Queen's speech, repetition makes them even more prominent, as Ophelia comes 'mit phantastischen Kränzen' and falls into the water 'mit ihren Kränzen in der Hand'. ${ }^{21}$

Ulla Hahn's 'Ophelia' is also defined by the 'Kranz' she bears, but this is 'mein Haar dunkler Hochzeitskranz'. ${ }^{22}$ Like Hardy's Eustacia pulled from the weir stream, whose 'black hair was looser now than either of them had ever seen it before', her hair freed is a typical motif of nineteenth-century watery femininity, common to Loreley and Undine. Dishevelled hair also indicated madness, or having been raped, in the Elizabethan theatre where Ophelia originated. Bobrowski's Ophelia poem refers to 'deines hellen Haares | Gelöste Strähne' too; Hahn's poem changes the perspective to first-person, 'mein Haar'. This overturns entirely the tradition, which never equated the lyric 'ich' with Ophelia: whereas Köhler's lyric 'ich' requests the role, and Kirsch brings her nearer as a sister-self, in Hahn's 'Ophelia' poem the lyric voice belongs utterly to the Ophelia that poets and painters have been observing for hundreds of years:

Schöner Fluß löst mir all mein

Haar dunkler Hochzeitskranz

Leckst mir in die Ohren den

${ }^{20}$ Gottfried Benn, 'Schöne Jugend', in Sämtliche Werke: Stuttgarter Ausgabe, ed. by Gerhard Schuster, 7 vols (Stuttgart: Klett-Cotta, I 986-2003), I: Gedichte I (I986), p. I I.

${ }^{21}$ Christoph Martin Wieland, Shakespeares theatralische Werke, ed. by Ernst Stadler (Berlin: Weidmannsche Buchhandlung, I9 I I), p. 477; William Shakespeare, Hamlet, Prinz von Dänemark, in Sämtliche Dramen, trans. by A. W. von Schlegel (Munich: Winkler, I975), pp. 589-70 I (p. 680).

${ }^{22}$ Ulla Hahn, 'Ophelia', in Freudenfeuer: Gedichte (Stuttgart: DVA, I985), p. 56. 


\author{
kitzligen Nabel drückst mir \\ blasige Küsse aus Nase und Mund \\ Schwingst meine Brüste verströmst dich \\ beständig vor und zurück \\ All mein Fleisch all dein Wasser \\ Winden und Winseln \\ Wie wollen sie eins sein in dir.
}

Sexual experience and death share the same image-space here, for the squirming and whimpering also denotes drowning. Like Hilbig's poem, which likewise has her wedded to the water, this poem represents Ophelia's dissolution into formlessness. But Hahn's imaginative construction of a carnal Ophelia involves voicing her, instead of silencing her. This poem shows how madness alters, depending on whether the madwoman speaks or is spoken. As Köhler's Ophelia addresses the clown (who in Hamlet will bury her), so Hahn's Ophelia addresses the river which drowns her. Hamlet is absent from this poem, for all that it evokes Ophelia's erotic love. It is not another human that Ophelia seeks in order to become whole: the 'ich' of 'Fleisch' is addressing herself to a 'du' of 'Fluß', amorphous elemental nature. The water itself, the agent of her death, is instated as lover, in place of Hamlet.

In Shakespeare, Ophelia sings wistful and bawdy ballads which use sexual overtones; now her interrupted song is continued by Hahn's poem voicing the liquid woman, whose motion conforms to that of the river. Her suicidal compulsion is written as union with the water. This points to earlier developments in the Ophelia myth, such as Johannes R. Becher's poems on L'Inconnue de la Seine, the unknown girl pulled from the Paris river. His 'Die Unbekannte aus der Seine' culminates with the drowned woman as 'du ewiges Fließen'. ${ }^{23}$ His 'Auferstehung der Inconnue' offers a vision of the woman rising 'von jenem ewigen Fließen, | Darin sie ruhte eine lange Zeit [. . . Ihr war als hätte sie sich ausgeruht'. ${ }^{24}$ Becher's poems thus, in the absence of the fact, observe death by drowning as a sweet release into wateriness. Hahn's poem takes up the idea that death in water is desired by the woman but voices her. She reclaims the Ophelia who feels too much and thus literally 'drowns in feeling' ${ }^{25}$

Both Hahn's poem 'Ophelia' and Hilde Domin's poem 'Element' make Hamlet absent and Ophelia immediately present; the poems cease to recall a memory and instead are located in the moment of drowning. ${ }^{26}$ Domin gives a different voice to Ophelia, however-not Hahn's effusive emotion but a cool voice devoid of hysteria:

Alle schwimmen in diesem Wasser

${ }^{23}$ Johannes R. Becher, 'Die Unbekannte aus der Seine', in Gesammelte Werke, ed. by JohannesR.-Becher-Archiv der Deutschen Akademie der Künste, i 8 vols (Berlin and Weimar: Aufbau Verlag, i 965-88), IV: Gedichte I936-I94I ( I966), p. 24 I.

${ }^{24}$ Becher, 'Auferstehung der Inconnue', in Gesammelte Werke, vi: Gedichte I949-I958 (I973), p. 2 I .

25 Showalter's phrase ('Representing Ophelia', p. 228).

${ }^{26}$ Hilde Domin, 'Element', in Der Baum blüht trotzdem: Gedichte (Frankfurt a.M.: Fischer, I 999), p. 3 I 


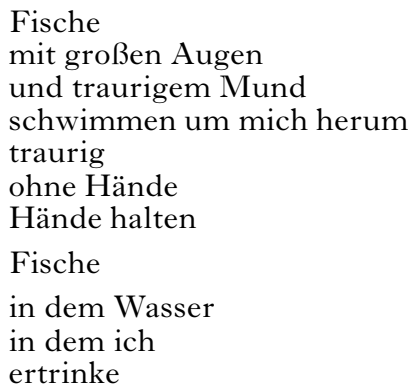

The Ophelia connection is hinted at in the references to swimming, fish, and water, but only becomes certain in the final word of this poem; what distinguishes Ophelia from a swimming mermaid (and the fish) is her drowning. Wieland had the Queen designate Ophelia 'wie eine Wasser-Nymphe' (where Schlegel translated 'mermaid-like' with 'sirenengleich'). ${ }^{27}$ Water, as in the Hahn poem above, is Ophelia's element in Domin's poem. It takes its cue from the Queen's speech in Hamlet:

[...] she chanted snatches of old tunes, As one incapable of her own distress,

Or like a creature native and indu'd

Unto that element [...]

$$
\text { (IV. 7. I78-8I) }
$$

Both the Wieland and Schlegel renderings of this speech retain the word 'Element' so central to Domin's reception of Ophelia. No punctuation interrupts the flow of Domin's poem, which voices Ophelia as an intelligible subject, communicating her own drowning, but also uses syntactical slippage as part of an evocation of watery possibility, in particular the fluidity of subject-object relations.

In contrast to the recent poems by female poets such as Hahn and Domin, contemporary male poets who write Ophelia never voice her. Instead, they erase her humanity altogether. In the ninth poem of Günter Kunert's 'Ländliche Elegien' sequence, the dead Ophelia is found not in the wild but in the waterbutt of a tended garden: ${ }^{28}$

$$
\begin{aligned}
& \text { In der Regentonne schwimmt } \\
& \text { Ophelia, gewandet } \\
& \text { in grauen Pelz. }
\end{aligned}
$$

The prominent figure of this poem is the anonymous gardener. Grey fur means this Ophelia is a rat, like Heym's 'Schwesterchen'. Heym located the rat in the female corpse, but in Kunert's poem the name of Ophelia has transferred to the rat itself. The name is also detached from the human body in Durs Grünbein's 2000 poem 'Hamlet The Thing'. Grünbein's poem does not have

\footnotetext{
${ }_{27}$ Wieland, Shakespeares theatralische Werke, p. 477; Shakespeare, Hamlet, Prinz von Dänemark, trans. by Schlegel, p. 68o.

${ }^{28}$ Günter Kunert, 'Ländliche Elegien, IX', in NachtVorstellung: Gedichte (Munich and Vienna: Hanser, I 999), p. 86.
} 
Ophelia upstage Hamlet in the way she does elsewhere in the lyric tradition, but it ends with two contrasted water myths, of Narcissus and of Ophelia: ${ }^{29}$

Prinz Hamlet in der Rolle des beleidigten Narziß,

Der durch die Blume spricht und in den Vorhang sticht,

Ein Automat, sein Ziel die Selbstzerstörung.

Der Ignorant, der alle Unschuld straft — Ophelia.

This Ophelia is victim of the 'Körperfresser'; she is the antithesis of a Narcissus who found his self in the water. ${ }^{30}$ In the Ophelia tradition, waters long brought dissolution to the female body, and in this poem Ophelia is only a name which signals the destroyed victim-she is not even syntactically integrated. Held up for decades as an unfortunate object to be pitied, Ophelia in the r 990 os gains viable subjectivity in the poems by female poets, while in Kunert's rat and Grünbein's 'Unschuld' the unfortunate object reappears in new, dehumanized guise.

Ophelia is always contemporary, reappearing as a gendering of death or a killing of woman. Redefining womanhood is one of the major concerns of twentieth-century western culture; far from being specific to the Expressionist era, writing Ophelia has been an enduring means of contesting that process of redefinition. The crucial development in the r 980 s and I 990 s is that of voicing Ophelia. In Shakespeare, a Gentleman says to the Queen that Ophelia 'speaks things in doubt, I That carry but half sense: her speech is nothing' (IV. 5. 6-7). The German poems by female poets defy this notion that 'ihre Red ist nichts', ${ }^{31}$ exchanging the silencing waters for waters which prompt her to speak. This is in contravention of Poe's assertion, the first part of which I cited at the outset to characterize even the twentieth-century reception of Ophelia:

The death, then, of a beautiful woman is, unquestionably, the most poetical topic in the world-and equally it is beyond doubt that the lips best suited for such a topic are those of a bereaved lover.

The contemporary female poets, whose Ophelia poems are examined here, forgo the lips of the bereaved lover and change the subject. In Köhler's and Hahn's poems Ophelia speaks her own desire; in Kirsch's and Domin's poems she reclaims the water. The voice of the observing voyeur is ousted, his pallid object replaced by the female speaker of the new Ophelia poems.

${ }^{29}$ Durs Grünbein, 'Hamlet The Thing', in Das erste Fahr: Berliner Aufzeichnungen (Frankfurt a.M.: Suhrkamp, $200 \mathrm{I})$, pp. I $46-47$.

${ }^{30}$ See Hanspeter Zürcher, Stilles Wasser: Narziß und Ophelia in der Dichtung und Malerei um I9oo (Bonn: Bouvier, I975).

${ }^{31}$ Shakespeare, Hamlet, Prinz von Dänemark, trans. by Schlegel, p. 668. 